\title{
Development of Evidence-based Nursing Practice Guidelines for Peripheral Intravenous Catheter Management in Hospitalized Children and Adult
}

\author{
Young-Ju Kim ${ }^{1}$, Sun-Mi Lee ${ }^{2}$, Ho-Ran Park ${ }^{2}$, Kyeong-Yae Sohng ${ }^{2} \&$ Seok-Jung Kim ${ }^{3}$ \\ ${ }^{1}$ Uijeongbu St. Mary's Hospital, Dept. of Nursing, The Catholic University of Korea, Kumoh-dong, Uijeongbu \\ City, Gyeonggi-do, Korea \\ ${ }^{2}$ College of Nursing, The Catholic University of Korea, Uijeongbu City, Gyeonggi-do, Korea \\ ${ }^{3}$ Uijeongbu St. Mary's Hospital, Dept. of Orthopedic Surgery, The Catholic University of Korea, Uijeongbu City, \\ Gyeonggi-do, Korea \\ Correspondence: Young-Ju Kim, R.N., MNSc, Dept. of Nursing, Uijeongbu St. Mary's Hospital, Kumoh-dong, \\ Uijeongbu City, Gyeonggi-do, 480-717, Korea.
}

Received: January 21, 2018

Accepted: February 4, $2018 \quad$ Online Published: February 12, 2018

doi:10.20849/ijsn.v3i1.309

URL: https://doi.org/10.20849/ijsn.v3i1.309

\begin{abstract}
Aims: The purpose of this study was to report on the development of evidence-based practice guidelines.

Design: Developmental research for practice guidelines.

Methods: The guidelines developmental process was designed according to a procedure provided by Scottish Intercollegiate Guidelines Network (SIGN). A first step, key clinical questions were selected. Next, 74 studies were selected from studies of 719 according to a search strategy, and then methodological quality of those studies was evaluated using assessment tool of SIGN. After the evaluation of draft guidelines including recommendations and their grades, the contents were modified. Last, definitive guidelines were evaluated using Appraisal of Guidelines for Research and Evaluation (AGREE) tool.

Result: The guidelines consist of three categories and 64 recommendations, i.e. nine recommendations for user before peripheral intravenous catheterization (PIVC), 26 recommendations during PIVC, and 29 recommendations after PIVC. Content validity was revealed to $70-78 \%$ by experts' agreement.
\end{abstract}

Conclusion: These guidelines were completed throughout systematic reviews and evaluations by clinical experts. Their contents are also included about overall managements for PIV therapy. Therefore these guidelines could help PIV practitioners to make evidence based decision.

Relevance to clinical practice: The method and result of this study are described specifically in figures, tables and appendix, which could give guidance to nurses who develop guidelines regarding other subjects.

Keywords: intravenous, peripheral catheterizations, guidelines, evidence based-nursing, evaluation research

\section{Introduction}

PIV therapy is frequently interrupted by complications (Ingram \& Lavery, 2005). Studies performed in pediatric medical facilities found that approximately $74 \%$ of the patients underwent PIVC (Noonan, Quigley, \& Curley, 2006).

Since it is important to maintain PIV therapies without complications, nurses should manage it in a standardized method (Kim JS, Lee YR, \& NS., 2012; Noonan et al., 2006). When evidence-based guidelines for the prevention of intravascular catheter-related infections introduced by the U.S. Center for Disease Control and Prevention were checked up, those were focused on a wide range of catheter-related injections rather than on PIV or child-specific information (O'Grady et al., 2011; O'Grady et al., 2002). Previous systematic reviews had reported the optimized peripheral device intravenous replacement period of PIV devices (Idvall \& Gunningberg, 2006; Webster, Osborne, Rickard, \& Hall, 2010). When viewed as a whole, the researches focused on the specific situation of PIVC, and the provided information was fragmentary (Dalal et al., 2009; Doniger, Ishimine, Fox, \& Kanegaye, 2009; Panebianco et al., 2009; Perry, Caviness, \& Hsu, 2011; Rickard, McCann, Munnings, \& 
McGrail, 2010; Small et al., 2008). Therefore the PIVC management should be explained in the context of a series as guidelines.

\section{Methods}

\subsection{Guidelines Users and Study Subjects}

The intended users of these guidelines are clinical practitioners. The intended study subjects are adult and children scheduled to receive PIV therapy. Contents limited to children were based on below 7 years of age. Classifications of pediatric patients are somewhat different among nations. Puberty stage is included or not. Since puberty-related hormonal change causes a variety of physical and mental changes (McMahon, C., Stryjewski, \& R., 2011) and it can vary considerably with age, only children $\leq 7$ years of age were considered.

\subsection{Ethical Approval}

Ethical approval was not required.

\subsection{Guidelines Development Process}

Development process was accomplished according to the guidelines provided by SIGN (Scottish Intercollegiate Guidelines Network). The development process was consists of eight-step (Figures 1 2).

\begin{tabular}{ll}
\hline Step 1 & Identification of guidelines development scope \\
\hline Step 2 & Assignment of level evidence from studies \\
\hline Step 3 & Decision regarding recommendation grades \\
\hline & Draft guidelines \\
\hline Step 4 & Experts' evaluation about the draft \\
\hline & \\
\hline Step 5 & Modification of the draft guidelines \\
\hline & \\
\hline Step 6 & Definitive guidelines \\
\hline Step 7 & Verification of its validity \\
\hline Step 8 & Figure 1. Process of developing guidelines
\end{tabular}

Figure 1. Process of developing guidelines 


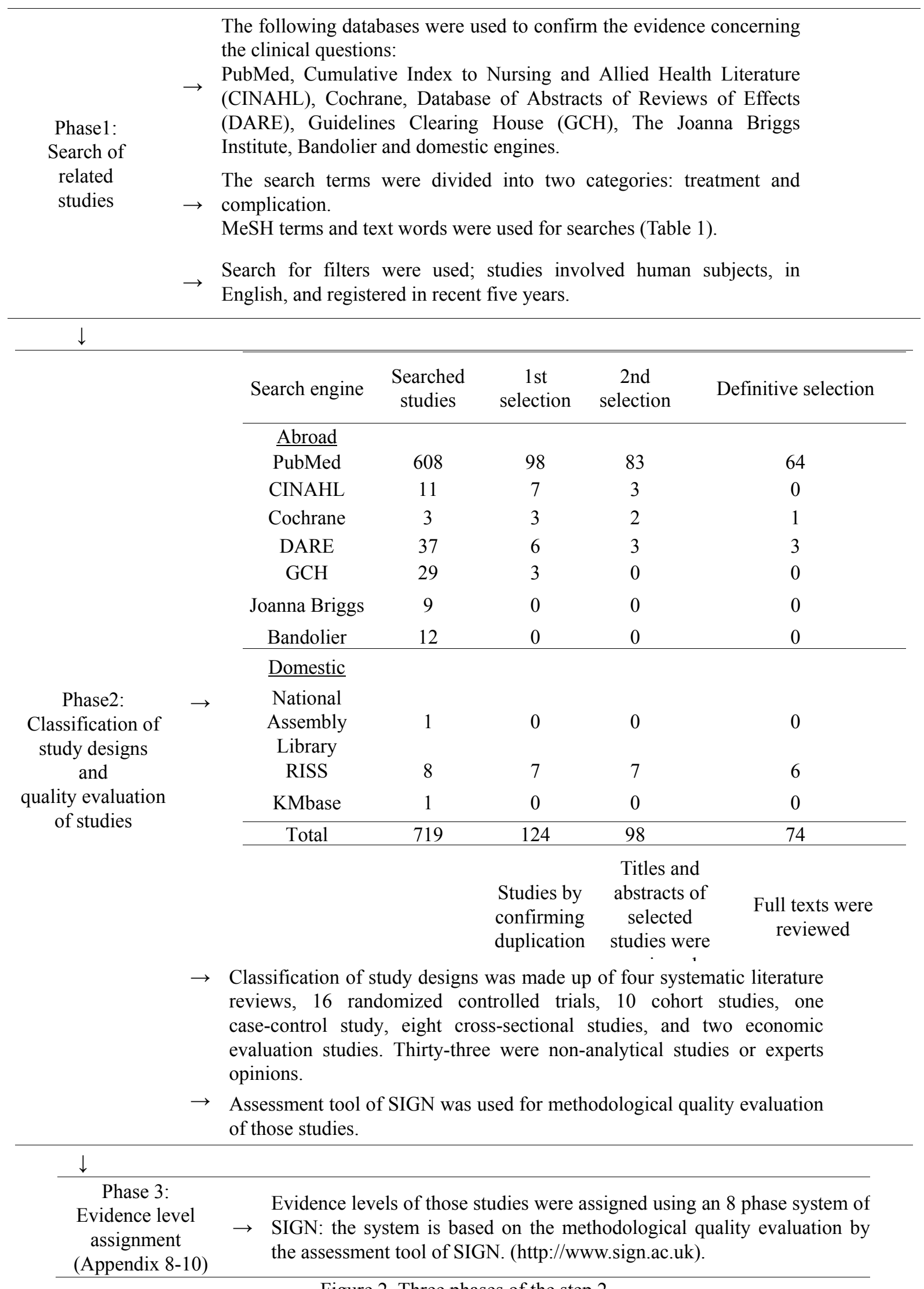

Figure 2. Three phases of the step 2 
Step 1. Identification of the guidelines development scope

To identify of contents and scope that would be included in guidelines, the key clinical questions were taken from comments of 15 nurses, including 10 pediatric ward nurses and five neonatal ward nurses, all of whom had more than two years of clinical experience in their respective clinical ward.

Twenty-two clinical questions were formulated, based on practitioner experience, literature search in order to identify the scope of guidelines. The PICO (P; Patient or Problem, I; Intervention, C; Comparison, O; Outcome) form was used ("Establish of Guidelines development plan," 2010) to present clinical questions (Appendix 1).

Step 2. Assignment of evidence levels from studies

This step was consisted of three phases. Medical Subject Headings (MeSH) terms and text words were used according to the designed search strategy at phase 1. (Table 1). The following search sources were used to confirm the evidence about the clinical questions; PubMed, Cumulative Index to Nursing and Allied Health Literature (CINAHL), Cochrane, Database of Abstracts of Reviews of Effects (DARE), Guidelines Clearing House (GCH), and The Joanna Briggs Institute, Bandolier and domestic engines. Total number of searched studies was 719 . Next 124 studies were selected by confirming duplication. 98 studies were selected through title and abstract review. 74 studies were selected through second full text review (Figure 2). Their study designs were classified and then methodological quality was evaluated at phase 2. Two nurses pursuing a nursing master's degree evaluated methodological quality of the selected studies that excluded non-analytical studies and expert opinions using an assessment tool of SIGN. To ensure objectivity, they conducted in separate rooms. As a result, evaluation about three studies did not coincide, so that issues were discussed by another evaluator pursuing a nursing master's degree. There were different opinions about confused variables; using of antibiotics, sample size (RCT-11, RCT-9; Appendix 2-2), and blinded control (CS-29; Appendix 2-3). At phase 3, evidence levels from those studies were assigned using an 8 phase system of SIGN.

Table 1. Search strategy; MeSH terms (1 6, 16 23), text words (7 10, 24)

\begin{tabular}{|c|c|}
\hline \multicolumn{2}{|l|}{ 1) Intravenous (Intravenous In*) } \\
\hline Intravenous Injections & Drip, Intravenous \\
\hline Injection, Intravenous & Drip Infusions \\
\hline Intravenous Infusions & Drip Infusion \\
\hline Infusion, Intravenous & Infusion, Drip \\
\hline Intravenous Drip & Infusions, Drip \\
\hline \multicolumn{2}{|l|}{ 2) Venipuncture } \\
\hline Phlebotomies & Venipuncture \\
\hline Venesection & Venipunctures \\
\hline \multicolumn{2}{|l|}{ Venesections } \\
\hline \multicolumn{2}{|l|}{ 3) Vein } \\
\hline \multicolumn{2}{|l|}{ Vein } \\
\hline \multicolumn{2}{|c|}{ 4) Peripheral Catheter* NOT Arter* NOT Bronchial } \\
\hline Peripheral Catheterization & Peripheral Arterial Catheterization \\
\hline Catheterizations, Peripheral & Arterial Catheterizations, Peripheral \\
\hline Peripheral Catheterizations & Catheterizations, Peripheral Arterial \\
\hline Peripheral Venous Catheterization & Peripheral Arterial Catheterizations \\
\hline Catheterizations, Peripheral Venous & Arterial Catheterization, Peripheral \\
\hline Peripheral Venous Catheterizations & Catheterization, Bronchial \\
\hline Venous Catheterizations, Peripheral & Bronchial Catheterization \\
\hline Catheterization, Peripheral Venous & Bronchial Catheterizations \\
\hline Venous Catheterization, Peripheral & Catheterizations, Bronchial \\
\hline Catheterization, Peripheral Arterial & \\
\hline
\end{tabular}




\begin{tabular}{ll}
\hline 5) Catheterizations & \\
\hline Cannulation & Catheters \\
Cannulations & Cannula \\
Catheter & Cannulas \\
\hline & \\
\hline 6) Catheter-related Infections & \\
\hline Catheter-related Infection & Infections, Catheter-related \\
Infection, Catheter-related & \\
\hline
\end{tabular}

\section{7) Infusion tubing}

8) Vascular assess

9) Line change

10) Replacement

11) \#1 OR \#2 OR \#3

12) \#5 OR \#6

13) \#7 OR \#8 OR \#9 OR \#10

14) \#11 OR \#12 OR \#13

15) \#14 AND \#4

\begin{tabular}{ll}
\hline 16) Prevention and control & \\
\hline Preventive therapy & Prevention \\
Prophylaxis & Control \\
Preventive measures & \\
\hline
\end{tabular}

\begin{tabular}{ll}
\hline 17) Methods & \\
\hline Study, Methodological & Methodological Studies \\
Methodological Study & Procedures \\
Studies, Methodological & Procedure \\
\hline & \\
\hline 18) Methods [Subheading] & \\
\hline Techniques & Methodology \\
Procedures & \\
\hline
\end{tabular}

\section{9) Infection Control}

\begin{tabular}{ll}
\hline 20) Safety Management & \\
\hline Management, Safety & Surveillance Programs, Hazard \\
Hazard Surveillance Program & Hazard Management \\
Hazard Surveillance Programs & Management, Hazard \\
Program, Hazard Surveillance & Hazard Control \\
Programs, Hazard Surveillance & Control, Hazard \\
Surveillance Program, Hazard & Hazard Controls \\
\hline
\end{tabular}




\begin{tabular}{|c|c|}
\hline \multicolumn{2}{|l|}{ 21) Anti-Inflammatory Agents } \\
\hline Agents, Anti-inflammatory & Agents, Anti-Inflammatory \\
\hline Anti-inflammatory & Anti-Inflammatories \\
\hline Anti-inflammatory Agents & Anti Inflammatories \\
\hline \multicolumn{2}{|l|}{ Agents, Anti-Inflammatory } \\
\hline \multicolumn{2}{|l|}{ 22) Infection } \\
\hline \multicolumn{2}{|l|}{ Infections } \\
\hline \multicolumn{2}{|l|}{ 23) Contamination, Equipment } \\
\hline Contaminations, Equipment & Equipment Contaminations \\
\hline \multicolumn{2}{|l|}{ 24) Complication } \\
\hline \multicolumn{2}{|l|}{ 25) \#17 OR \#18 } \\
\hline \multicolumn{2}{|l|}{ 26) \#16 OR \#20 OR \#21 } \\
\hline \multicolumn{2}{|l|}{ 27) \#19 OR \#22 OR \#23 OR \#24 } \\
\hline \multicolumn{2}{|l|}{ 28) \#25 OR \#26 OR \#27 } \\
\hline \multicolumn{2}{|l|}{ 29) \#28 AND \#15 } \\
\hline \multicolumn{2}{|c|}{ The retrieved documents based on strategy } \\
\hline$\# 1$ OR \#2 OR \#3 & 397,595 \\
\hline \#5 OR \#6 & 176,656 \\
\hline$\# 7$ OR \#8 OR \#9 OR \#10 & 208,871 \\
\hline \#14 AND \#4 & 3,666 \\
\hline \#17 OR \#18 & 367,0137 \\
\hline$\# 16$ OR \#20 OR \#21 & $1,232,410$ \\
\hline \#19 OR \#22 OR \#23 OR \#24 & $1,437,203$ \\
\hline \#25 OR \#26 OR \#27 & $5,554,419$ \\
\hline \#28 AND \#15 & 2,663 \\
\hline
\end{tabular}

Step 3. Decision regarding recommendation grades

Recommendations from the evidence were graded according to SIGN grading system ("SIGN 50: A guidelines developer's handbook," 2008). The grade of recommendation is moved to 'A' from ' $\mathrm{D}$ ' according to the evidence levels and a number of the supported studies.

Step 4. Draft guidelines

The recommendations and their grades were described in the draft guidelines.

Step 5. Experts' evaluation about the draft

A group for draft guidelines evaluation was composed of experts regarding pediatric PIV therapy. In other words, seven practical experts and seven theoretical experts were selected; nurses who worked in pediatric wards, neonatal wards, pediatric emergency center and practitioners who administer and educate about intravenous therapy. The experts evaluated on adequacy, effectiveness, and application possibility of the recommendations using RAND corporation scale (Sachs GS, Printz DJ, Kahn DA, Carpenter D, \& JP., 2005). The evaluation results using Fehring method were converted into a one-point scale; measurement of 1, 2, 3, 4, and/or 5 indicated respective points of $0.0 .25,0.5,0.75$, and 1 (Fehring, 1987). Recommendations pointed exceeding 0.80 indicate classification of core contents, and pointed of 0.80-0.60 indicate classification as supportive contents and pointed 
$<0.60$ indicate that contents should be modified or removed from the guidelines (EJ, 2003; Johnson \& Maas, 1998).

Step 6. Modification of the draft

Depending upon the aforementioned point of step 5, experts opinion analysis and literature review were conducted in order to modify uncertain recommendations.

Step 7. Definitive guidelines

The guidelines were consisted of three categories and 64 recommendations. They are nine recommendations before PIVC, 26 recommendations during PIVC, and 29 recommendations after PIVC.

Step 8. Verification of its validity

To evaluate validity of the definitive guidelines content, Tool of Appraisal of Guidelines for Research and Evaluation (AGREE) was used ("AGREE Korean version," 2001). And, experts consisted of six individuals with extensive theoretical knowledge regarding clinical guidelines: 1) one professor of nursing fundamentals 2) one infection control expert 3) one pediatrician 4) one pediatric orthopedic surgeon 5) two experts, both with Ph.Ds. in Nursing, with more than 15 years of clinical experience.

\section{Results}

\subsection{Methodological Quality Assessment for Assignment of the Evidence Level}

Step 2, The result of the methodological quality assessment using the assessment tool of SIGN became evidences level for clinical questions which were derived from the guidelines development scope of step 1.

Four systematic literature reviews, sixteen randomized controlled trials, ten prospective cohort studies, one case-control study, nine cross-sectional studies and two economic evaluation studies were evaluated (Appendix 2-1 2-5).

\subsection{Decision of Recommendation Grade}

The recommendations were graded by the tool of SIGN. The grade was assigned from 'A' to 'D' according to number of supported studies, evidence level and practical possibility. Step 3, the numbers of A, B, C, and D were six, 22, 13, and 23, respectively.

\subsection{Draft Guidelines Evaluation}

Draft guidelines derived in step 4 were evaluated in step 5. The adequacy and effectiveness scores of below 0.60 were two; 1) Application of lidocaine cream or 1\% lidocaine using needle-free jet injection prior to insertion. 2) When a peripheral catheter is inserted to lower extremities, patients over eight years old are examined about a risk of thrombophlebitis by a physician.

And a low application was four: 3) if PIV therapy was required for more than six days, peripherally inserted central vein or midline should be regarded as alternative methods 4) PIV detection using ultrasound or near-infrared imaging 5) to compensate for the vasoconstrictor effect of lidocaine, glyceryl trinitrate cream that expands blood vessels should be applied for 10 minutes before PIVC 6) clean gloves should be worn in order to protect practitioners (Tables 2 3).

Table 2. Scores of low-graded recommendations in the experts evaluation of the draft

\begin{tabular}{|c|c|c|c|}
\hline \multirow{2}{*}{$\begin{array}{l}\text { Classified recommendation } \\
\text { of low grade }\end{array}$} & Appropriateness & Applicability & Effectiveness \\
\hline & \multicolumn{3}{|c|}{$\mathrm{M}(\mathrm{SD})$} \\
\hline 1) Lidocaine application prior to catheterization & $0.59(0.19)$ & $0.42(0.26)$ & $0.57(0.19)$ \\
\hline $\begin{array}{l}\text { 2) Physician's prescription for low extremities } \\
\text { catheterization in a child > eight years of age }\end{array}$ & $0.58(0.25)$ & $0.50(0.25)$ & $0.59(0.21)$ \\
\hline $\begin{array}{l}\text { 3) Catheters remaining in the peripherally } \\
\text { inserted central vein or midline at least six } \\
\text { days }\end{array}$ & $0.66(0.30)$ & $0.49(0.27)$ & $0.66(0.30)$ \\
\hline $\begin{array}{l}\text { 4) Detection using ultrasound or near-infrared } \\
\text { imaging }\end{array}$ & $0.71(0.19)$ & $0.43(0.26)$ & $0.63(0.21)$ \\
\hline $\begin{array}{l}\text { 5) Glyceryl trinitrate cream application prior to } \\
\text { catheterization }\end{array}$ & $0.61(0.22)$ & $0.41(0.27)$ & $0.60(0.26)$ \\
\hline
\end{tabular}



6) Wearing clean gloves
$0.82(0.21)$
$0.55(0.28)$
$0.78(0.25)$
7) Compliance with the drying time of Iodine
$0.80(0.29)$
$0.56(0.29)$
$0.76(0.27)$
8) Mixture of $70 \%$ alcohol and $2 \%$ chlorhexidine
$0.79(0.18)$
$0.57(0.28)$
$0.77(0.20)$

Table 3. Reasons for low-graded recommendations in the experts' evaluation of the draft

\begin{tabular}{ll}
\hline Reason & Recommendation of low grade \\
\hline Lack of resource (budget, installation) & 1 ), 4), 5), 8), \\
Lack of resource (Experts) & 3 ), 4) \\
Lack of awareness & $1), 2), 3), 5), 6)$ \\
Difficulty (time consuming, inconvenient) & $1), 6), 7)$ \\
Discomfort of children & $1)$ \\
\hline
\end{tabular}

\subsection{Modification of the Draft Guidelines}

Step 6, the experts opinions about recommendations need to be deleted were as follows: 1) lidocaine cream or $1 \%$ lidocaine using needle-free jet injection causes blood vessels constriction, waiting period is needed after lidocaine application; such a process becomes more complicated if an insertion site should be changed, and then additional medical expenses are incurred 2) PIV detection using the ultrasound or near-infrared imaging was evaluated as an insufficient recommendation from a lack of awareness and evidence.

The experts opinions about recommendations need to be modified were as follows: 1) The prescription that allows low extremities to be inserted with PIV catheters for children $\geq$ eight years of age, the recommendation was so modified that risk factors would be described and any agreement/dissent was recorded. 2) The recommendation for a peripherally inserted central catheter or a midline catheter is limited by situations where there is a lack of professionals to perform the procedure. Therefore, the information was modified as professional staff training and validation of the staffing. 3) The recommendation was modified as the use of clean gloves would not always be required due to the difficulty of detecting a vein, except for cases where an infective disease of patient or hand injury of practitioner is suspected.

\subsection{Definitive Guidelines Assessment}

Step 7, the definitive guidelines were evaluated by the six experts using AGREE tool. The overall content validity of these guidelines scored $83 \%$ and the domain-specific scores were between $70-78 \%$ (Table 4 ).

Table 4. Content validity results of the guidelines

\begin{tabular}{lcccc}
\hline \multirow{2}{*}{ Domain } & No. of items & \multicolumn{2}{c}{ Mean } & Standardized domain \\
\cline { 3 - 4 } & & Min & Max & score (\%) \\
\hline Scope and purpose & 3 & 2.8 & 4.0 & 74 \\
Stakeholder involvement & 4 & 2.8 & 3.5 & 72 \\
Rigor of development & 7 & 3.0 & 3.9 & 78 \\
Clarity and presentation & 4 & 2.5 & 3.5 & 70 \\
Applicability & 3 & 2.7 & 4.0 & 76 \\
Editorial independence & 2 & 3.0 & 4.0 & 78 \\
Overall assessment & 1 & 3.0 & 4.0 & 83 \\
\hline
\end{tabular}

\subsection{Definitive Guidelines}

Step 8 , these guidelines consist of three categories and 64 recommendations were defined. The three categories consist of recommendation in, before, and after PIVC (Appendix 8-10). 


\section{Discussion}

The success rate of PIVC using the new methods (Doniger et al., 2009) did not higher than the conventional methods (Panebianco et al., 2009; Perry et al., 2011). Therefore, the recommendation was not included in these guidelines. However, PIVC using an improved method should be sought so as to reduce pain, anxiety, and tissue damage. Therefore, further evaluations are needed based on pain relief, cost of lidocaine, and patient satisfaction.

Iodine requires about two minutes for drying after being applied (O'Grady et al., 2002) and the skin is stained with darkened red, so the detection of veins becomes difficult. But $2 \%$ chlorhexidine disinfectant mixed with $70 \%$ alcohol requires only thirty seconds (Aziz, 2009; O'Grady et al., 2011) and the skin is not stained. Also, that disinfectant is more effective in coagulase-negative staphylococcus and streptococcus infection than other disinfectants (Small et al., 2008).

The recommendation regarding the transparent sterile dressing was included these guidelines, but expert evaluated it as relatively lower probability because additional medical payment was incurred if health care's policy did not permit using of that dressing. However, injection site observation through the transparent sterile dressing should be guaranteed in order to perform PIV catheter replacement depending on the patient's clinical symptoms.

The catheter replacement depending on patient's clinical symptoms shall reduce pain, stress, and tissue damage. So, practitioners could manage other interventions due to reduction in the PIVC time. In addition, medical cost savings can be expected through a reduction of PIV consumables. (Webster et al., 2010).

\section{Conclusion}

These practical guidelines were based on the clinical questions asked by practitioners who actually performed PIVC management, and the search strategy consisted with the phases of 3 was used to find evidence regarding the clinical questions. For the content validity of guidelines, twice evaluation processes were undergone by many relevant experts.

The number of recommendations grade "A" is six: 1) The formation of PIV injection team 2) Although skin is sterilized, if the skin is touched again by hands, the area is assumed to be contaminated 3) PIV Catheters should be re-placed only in cases of complications 4) The fluid set injected glucose and amino acid independently should not be replaced within 72 or 96 hours unless there is a special condition requiring it. 5) According to an increased number of peripherally injected medications, the complication rate shall be increased. 6) Risk of phlebitis shall be increased when irritating medication is injected. The recommendation graded " $\mathrm{B}$ " is twenty-two, "C" thirteen, and " $D$ " twenty-three.

\section{What This Paper Adds}

Various nursing interventions are performed for peripheral catheterization. Also during the practice, practitioners may have many decisions-making in accordance with various conditions. At that time, these recommendations and its grades could be considered. The higher of a grade, the more accurate interventions should be performed although situations shall be different.

\section{Acknowledgement}

Special thanks to Bonnie Hami, MA (USA) for editing this manuscript.

\section{References}

Aziz, A.M. (2009). Improving peripheral IV cannula care: implementing high-impact interventions. $B r J$ Nurs, 18(20), 1242-1246. https://doi.org/10.12968/bjon.2009.18.20.45116

Dalal, S.S., Chawla, D., Singh, J., Agarwal, R.K., Deorari, A.K., \& Paul, V.K. (2009). Limb splinting for intravenous cannulae in neonates: a randomised controlled trial. Arch Dis Child Fetal Neonatal Ed, 94(6), 394-396. https://doi.org/10.1136/adc.2008.147595

Doniger, S.J., Ishimine, P., Fox, J.C., \& Kanegaye, J.T. (2009). Randomized controlled trial of ultrasound-guided peripheral intravenous catheter placement versus traditional techniques in difficult-access pediatric patients. Pediatr Emerg Care, 25(3), 154-159. https://doi.org/10.1097/PEC.0b013e31819a8946

EJ, L. (2003). Validation of Nursing Care Sensitive Outcomes related to Knowledge. Journal of Korean Academy of Nursing, 33(5), 625-632. https://doi.org/10.4040/jkan.2003.33.5.625

Establish of Guidelines Development Plan. (2010). from Korean Medical Guidelines Information Center [KoMGI]. Retrieved from http://www.guidelines.or.kr 
Fehring, R.J. (1987). Methods to validate nursing diagnoses. Heart Lung, $16(6$ Pt 1), 625-629.

Idvall, E., \& Gunningberg, L. (2006). Evidence for elective replacement of peripheral intravenous catheter to prevent thrombophlebitis: a systematic review. $J$ Adv Nurs, 55(6), 715-722. https://doi.org/10.1111/j.1365-2648.2006.03962.x

Ingram, P., \& Lavery, I. (2005). Peripheral intravenous therapy: key risks and implications for practice. Nurs Stand, 19(46), 55-64. https://doi.org/10.7748/ns2007.09.22.1.44.c4613

Johnson, M., \& Maas, M. (1998). Implementing the Nursing Outcomes Classification in a practice setting. Outcomes Manag Nurs Pract, 2(3), 99-104.

Kim, J.S., Lee, Y.R., \& NS., K. (2012). Effects of the Structured Nursing Intervention for Caregivers on Maintenance of Intravenous Infusions in Infants. Child Health Nurs Res, 18(3), 135-142. https://doi.org/10.4094/jkachn.2012.18.3.135

McMahon, C.M., \& Stryjewski, R.G. (2011). Pediatrics. Philadelphia, PA: Saunders/Elsevier.

Noonan, C., Quigley, S., \& Curley, M.A. (2006). Skin integrity in hospitalized infants and children: a prevalence survey. J Pediatr Nurs, 21(6), 445-453. https://doi.org/10.1016/j.pedn.2006.07.002

O'Grady, N.P., Alexander, M., Burns, L.A., Dellinger, E.P., Garland, J., Heard, S.O., ... Saint, S. (2011). Guidelines for the prevention of intravascular catheter-related infections. Am J Infect Control, 39(4 Suppl 1), S1-34. https://doi.org/10.1016/j.ajic.2011.01.003

O'Grady, N.P., Alexander, M., Dellinger, E.P., Gerberding, J.L., Heard, S.O., Maki, D.G., ... Weinstein, R.A. (2002). Guidelines for the prevention of intravascular catheter-related infections. Centers for Disease Control and Prevention. MMWR Recomm Rep, 51(RR-10), 1-29.

Panebianco, N.L., Fredette, J.M., Szyld, D., Sagalyn, E.B., Pines, J.M., \& Dean, A.J. (2009). What you see (sonographically) is what you get: vein and patient characteristics associated with successful ultrasound-guided peripheral intravenous placement in patients with difficult access. Acad Emerg Med, 16(12), 1298-1303. https://doi.org/10.1111/j.1553-2712.2009.00520.x

Perry, A.M., Caviness, A.C., \& Hsu, D.C. (2011). Efficacy of a near-infrared light device in pediatric intravenous cannulation: a randomized controlled trial. Pediatr Emerg Care, 27(1), 5-10. https://doi.org/10.1097/PEC.0b013e3182037caf

Rickard, C.M., McCann, D., Munnings, J., \& McGrail, M.R. (2010). Routine resite of peripheral intravenous devices every 3 days did not reduce complications compared with clinically indicated resite: a randomised controlled trial. BMC Med, 8, 53. https://doi.org/10.1186/1741-7015-8-53

Sachs, G.S., Printz, D.J., Kahn, D.A., Carpenter, D., \& JP., D. (2005). The Expert Consensus Guidelines Series: Medication Treatment of Bipolar Disorder. Retrieved from http://www.psychguides.com

SIGN 50: A guidelines developer's handbook. (2008). From Scottish Intercollegiate Guidelines Network [SIGN] Retrieved from http://www.sign.ac.uk/methopology/index.html

Small, H., Adams, D., Casey, A.L., Crosby, C.T., Lambert, P.A., \& Elliott, T. (2008). Efficacy of adding 2\% (w/v) chlorhexidine gluconate to $70 \%(\mathrm{v} / \mathrm{v})$ isopropyl alcohol for skin disinfection prior to peripheral venous cannulation. Infect Control Hosp Epidemiol, 29(10), 963-965. https://doi.org/10.1086/590664

Webster, J., Osborne, S., Rickard, C., \& Hall, J. (2010). Clinically-indicated replacement versus routine replacement of peripheral venous catheters. Cochrane Database Syst Rev(3), CD007798. https://doi.org/10.1002/14651858.CD007798.pub2

\section{Copyrights}

Copyright for this article is retained by the author(s), with first publication rights granted to the journal.

This is an open-access article distributed under the terms and conditions of the Creative Commons Attribution license (http://creativecommons.org/licenses/by/4.0/). 


\section{Appendix 1.}

- $\quad 1 \sim 6$ : before peripheral intravenous catheterization

- 7 15: during peripheral intravenous catheterization

- 16 22: after peripheral intravenous catheterization

1. Is it effective for prevention of complications that practitioners understand the general characteristics of the pediatric patient?

2. Does it reduce the complications of children's peripheral intravenous therapy to inform about their disease?

3. Is the personal explanation more helpful for the prevention of complications than general information?

4. Prior to the catheterization, is it appropriate for the prevention of complications to exchange common information with caregivers?

5. When repetitive venipunctures are required, does a central catheterization can be substituted for PIV?

6. Is it necessary in order to prevent complications to use regulated tools for assessing the skin into which a peripheral catheter be inserted?

7. Does family participation help to reduce anxiety and improve children's adaptation during peripheral catheterization?

8. Is the specialized, peripheral intravenous team more effective?

9. Does it reduce complications to select a smaller gauge catheter?

10. Could it reduce of complications that only hand hygiene is maintained without wearing disinfected gloves?

11. Is the $2 \%$ chlorhexidine more effective as a skin disinfectant?

12. Does the most visible vein to be recommended for catheterization?

13. Is it more efficient for the prevention of complications to insert a catheter into lower extremities than upper?

14. Could it prevent complications to support the peripheral catheterization site using a splint?

15. Is it more effective to use a topical anesthetic for children's pain relief during peripheral catheterization?

16. Does it prevent complications to replace peripheral intravenous catheter routinely?

17. Does it prevent complications to replace extension devices routinely, i.e. extension tube and 3-way stopcock, and infusion set?

18. Does it prevent complications to use assessment tools about phlebitis or infiltration?

19. Does the use of dressing devices affect to complications?

20. Is it more secure to inject via an infusion pump than natural dropping?

21. Is it beneficial to recognize what kind of drug to be administered via peripheral veins?

22. Does it prevent complications to explain how can monitor its symptoms to children and their caregivers?

\section{Appendix 2-1. Quality appraisal of the systematic review}

Study topics for peripheral intravenous catheters were selective replacement (SR-1, SR-4), time to replacement of the infusion set (SR-2), drug injection via peripheral vein, and the duration of catheter placement (SR-3).

\begin{tabular}{lccccccc}
\hline No & $\begin{array}{c}\text { Focused } \\
\text { question }\end{array}$ & Methodology & $\begin{array}{c}\text { Literature } \\
\text { search }\end{array}$ & Quality assess & $\begin{array}{c}\text { Combining } \\
\text { reasonable }\end{array}$ & $\begin{array}{c}\text { Evidence- based } \\
\text { conclusion }\end{array}$ & $\begin{array}{c}\text { Overall } \\
\text { assessment }\end{array}$ \\
\hline SR-1 & 1 & 1 & 1 & 1 & 2 & 1 & ++ \\
SR-2 & 1 & 1 & 2 & 2 & 2 & 1 & ++ \\
SR-3 & 1 & 1 & 2 & 2 & 3 & 1 & + \\
SR-4 & 1 & 1 & 2 & 1 & 1 & 2 & ++ \\
\hline
\end{tabular}

SR, Systematic review; 1, Well-covered; 2, Adequately addressed; 3, Poorly addressed; 4, Not addressed; 5, Not reported; 6 , Not applicable; ++, All or most of the criteria have been fulfilled; +, Some of the criteria have been fulfilled; -, Few or no criteria fulfilled. 


\section{Appendix 2-2. Quality appraisal of the randomized controlled trial}

Study topics included the comparative study of a $2 \%$ chlorhexidine disinfectant mixed with $70 \%$ alcohol and existing skin antiseptic (RCT-5), regular exchange of peripheral intravenous catheters and selective exchange (RCT-6, RCT-7, RCT-9, RCT-12, RCT-18), moist and dry heat therapy for vasodilatation (RCT-8), application comparison between existing technology and ultrasound and near-infrared imaging for the detection of peripheral veins (RCT-10, RCT-13), comparison of factors of peripheral intravenous maintenance and complications (RCT-11), comparison of lidocaine and nitrous oxide and ethyl chloride for pain relief upon catheter insertion (RCT-14, RCT-15, RCT-16), PICC and Midline catheter (RCT-17), directional effect of bevel (RCT-19), and effects of a splint for peripheral intravenous catheter support (RCT-20).

\begin{tabular}{lccccccccccc}
\hline No & $\begin{array}{l}\text { Focused } \\
\text { question }\end{array}$ & $\begin{array}{c}\text { Assign } \\
\text {-ment }\end{array}$ & $\begin{array}{c}\text { Conceal } \\
\text {-ment }\end{array}$ & Blind Similarity & $\begin{array}{c}\text { Treated } \\
\text { equally }\end{array}$ & $\begin{array}{c}\text { Measure } \\
\text {-ment }\end{array}$ & Analysis & Drop & $\begin{array}{c}\text { Multi } \\
\text {-site }\end{array}$ & $\begin{array}{c}\text { Overall } \\
\text { assessment }\end{array}$ \\
\hline RCT-5 & 1 & 1 & 4 & 4 & 5 & 2 & 2 & 2 & 3 & 5 & + \\
RCT-6 & 1 & 1 & 6 & 6 & 2 & 2 & 2 & 2 & 2 & 6 & ++ \\
RCT-7 & 1 & 1 & 3 & 3 & 2 & 2 & 2 & 2 & 1 & 3 & ++ \\
RCT-8 & 1 & 1 & 6 & 6 & 3 & 5 & 2 & 2 & 2 & 6 & + \\
RCT-9 & 1 & 1 & 6 & 6 & 4 & 5 & 3 & 3 & 2 & 6 & - \\
RCT-10 & 1 & 1 & 6 & 6 & 3 & 3 & 2 & 3 & 1 & 6 & + \\
RCT-11 & 1 & 2 & 3 & 3 & 4 & 5 & 2 & 2 & 1 & 6 & + \\
RCT-12 & 1 & 1 & 2 & 2 & 3 & 3 & 2 & 2 & 1 & 6 & + \\
RCT-13 & 1 & 1 & 6 & 6 & 3 & 3 & 3 & 2 & 1 & 6 & + \\
RCT-14 & 1 & 1 & 6 & 6 & 3 & 3 & 3 & 1 & 1 & 6 & + \\
RCT-15 & 1 & 1 & 1 & 1 & 3 & 3 & 3 & 3 & 1 & 6 & + \\
RCT-16 & 1 & 1 & 1 & 1 & 2 & 5 & 2 & 2 & 2 & 6 & + \\
RCT-17 & 1 & 1 & 6 & 6 & 2 & 2 & 2 & 3 & 1 & 6 & + \\
RCT-18 & 1 & 2 & 6 & 6 & 4 & 4 & 3 & 2 & 3 & 6 & - \\
RCT-19 & 1 & 2 & 6 & 6 & 5 & 4 & 2 & 1 & 2 & 6 & - \\
RCT-20 & 1 & 2 & 6 & 6 & 3 & 5 & 2 & 3 & 2 & 6
\end{tabular}

RCT, Randomized controlled trial; 1, Well-covered; 2, Adequately addressed; 3, Poorly addressed; 4, Not addressed; 5, Not reported; 6 , Not applicable; ++, All or most of the criteria have been fulfilled; +, Some of the criteria have been fulfilled; -, Few or no criteria fulfilled.

\section{Appendix 2-3. Quality appraisal of cohort studies}

Study topics included the comparative study of phlebitis and its factors in peripheral intravenous catheters (CS-21, CS-22, CS-23, CS-25, CS-26, CS-28, CS-30), the success rate of peripheral vein detection using ultrasound (CS-24), the contamination rate associated with the use of a peripheral intravenous catheter (CS-27), and comparison of peripheral intravenous and catheter-related complications occurring in the Emergency Room and in the general hospital environment (CS-29).

\begin{tabular}{|c|c|c|c|c|c|c|c|c|c|c|}
\hline No & $\begin{array}{l}\text { Focused } \\
\text { question }\end{array}$ & $\begin{array}{c}\text { Source } \\
\text { population }\end{array}$ & $\begin{array}{c}\text { Participants } \\
\text { division }\end{array}$ & $\begin{array}{l}\text { Eligible } \\
\text { subjects }\end{array}$ & $\begin{array}{c}\text { Drop } \\
\text { out }\end{array}$ & Blind & $\begin{array}{c}\text { Outcome } \\
\text { assessment }\end{array}$ & Con-founder & Analysis & $\begin{array}{c}\text { Overall } \\
\text { assessment }\end{array}$ \\
\hline CS-21 & 1 & 1 & 2 & 5 & 5 & 5 & 3 & 3 & 2 & + \\
\hline CS-22 & 1 & 1 & 5 & 1 & 5 & 5 & 2 & 3 & 2 & + \\
\hline CS-23 & 1 & 1 & 4 & 1 & 1 & 2 & 1 & 2 & 2 & ++ \\
\hline CS-24 & 1 & 1 & 2 & 2 & 5 & 3 & 2 & 3 & 2 & + \\
\hline CS-25 & 1 & 1 & 2 & 2 & 2 & 2 & 2 & 3 & 2 & ++ \\
\hline CS-26 & 1 & 1 & 5 & 1 & 1 & 3 & 3 & 3 & 2 & + \\
\hline CS-27 & 1 & 1 & 2 & 2 & 2 & 6 & 5 & 4 & 2 & + \\
\hline CS-28 & 1 & 1 & 5 & 5 & 1 & 5 & 3 & 4 & 2 & + \\
\hline CS-29 & 1 & 2 & 5 & 2 & 4 & 5 & 3 & 3 & 3 & - \\
\hline CS-30 & 1 & 1 & 2 & 2 & 1 & 4 & 2 & 3 & 2 & + \\
\hline
\end{tabular}

CS, Cohort studies; 1, Well-covered; 2, Adequately addressed; 3, Poorly addressed; 4, Not addressed; 5, Not reported; 6 , Not applicable; ++, All or most of the criteria have been fulfilled; +, Some of the criteria have been fulfilled; -, Few or no criteria fulfilled. 


\section{Appendix 2-4. Quality appraisal of case-control studies and cross-sectional studies}

The topics were education and the performance of peripheral intravenous catheterization. Nine, cross-sectional studies (CSSs) were evaluated. CSS topics were regional differences in the management of peripheral intravenous catheters (CSS-33), inconsistent guidelines and the nursing practice regarding peripheral intravenous catheters (CSS-32), recognition of and performance for preventing peripheral intravenous complications (CSS-34), factors influencing peripheral intravenous catheter failure (CSS-35), peripheral intravenous catheter reinsertion factors (CSS-36, CSS-39, CSS-40), pain caused by peripheral intravenous insertion (CSS-37), and selective replacement of peripheral intravenous catheters (CSS-38).

\begin{tabular}{lcccccccccc}
\hline No & $\begin{array}{c}\text { Focused Comparable } \\
\text { question }\end{array}$ & $\begin{array}{c}\text { Same } \\
\text { exclusion } \\
\text { criteria }\end{array}$ & $\begin{array}{c}\text { Percentage } \\
\text { of each }\end{array}$ & $\begin{array}{c}\text { Drop } \\
\text { out }\end{array}$ & Similarity & Blind & $\begin{array}{c}\text { Measure } \\
\text { ment }\end{array}$ & $\begin{array}{c}\text { Con Overall } \\
\text { founder assessment }\end{array}$ \\
\hline CCS-31 & 1 & 6 & 6 & 6 & 1 & 4 & 6 & 2 & 5 & + \\
CSS-32 & 1 & 3 & 3 & 3 & 5 & 2 & 4 & 2 & 3 & - \\
CSS-33 & 1 & 4 & 4 & 2 & 3 & 3 & 3 & 2 & 3 & + \\
CSS-34 & 1 & 6 & 6 & 6 & 1 & 3 & 6 & 2 & 3 & + \\
CSS-35 & 1 & 6 & 6 & 6 & 1 & 3 & 6 & 2 & 2 & + \\
CSS-36 & 1 & 6 & 6 & 6 & 1 & 3 & 6 & 2 & 3 & + \\
CSS-37 & 1 & 6 & 6 & 6 & 1 & 3 & 6 & 2 & 2 & + \\
CSS-38 & 1 & 6 & 6 & 6 & 3 & 3 & 6 & 2 & 2 & + \\
CSS-39 & 1 & 6 & 6 & 6 & 1 & 3 & 6 & 2 & 2 & + \\
CSS-40 & 1 & 6 & 6 & 6 & 3 & 3 & 6 & 3 & 3 & + \\
\hline
\end{tabular}

CCS, Case-control studies; CSS, Cross-sectional studies; 1, Well-covered; 2, Adequately addressed; 3, Poorly addressed; 4, Not addressed; 5, Not reported; 6 , Not applicable; ++, All or most of the criteria have been fulfilled;

+ , Some of the criteria have been fulfilled; -, Few or no criteria fulfilled.

\section{Appendix 2-5. Quality appraisal of the economic evaluation studies}

Effectiveness analysis topics considering the cost were chlorhexidine and iodine, and a comparison was made of pain relief medications.

\begin{tabular}{lcccccccc}
\hline No & $\begin{array}{c}\text { Study } \\
\text { question }\end{array}$ & $\begin{array}{c}\text { Economic } \\
\text { importance }\end{array}$ & $\begin{array}{c}\text { Cost } \\
\text { analysis }\end{array}$ & $\begin{array}{c}\text { Information } \\
\text { of relevance }\end{array}$ & $\begin{array}{c}\text { Patients } \\
\text { participated }\end{array}$ & $\begin{array}{c}\text { Scale of the } \\
\text { cost }\end{array}$ & $\begin{array}{c}\text { Statistical } \\
\text { measurement }\end{array}$ & $\begin{array}{c}\text { Overall } \\
\text { assessment }\end{array}$ \\
EE-40 & 1 & 3 & 3 & 3 & 6 & 2 & 5 & + \\
EE-41 & 1 & 3 & 3 & 3 & 6 & 2 & 5 & + \\
\hline
\end{tabular}

EE, Economic evaluation; 1, Well-covered; 2, Adequately addressed; 3, Poorly addressed; 4, Not addressed; 5 , Not reported; 6, Not applicable; ++, All or most of the criteria have been fulfilled; +, Some of the criteria have been fulfilled; -, Few or no criteria fulfilled.

Appendix 3. Study in which a methodological quality assessment was performed for development of the guidelines for peripheral intravenous administration in pediatric patients.

\section{1) Systematic review}

SR-1. Webster, J., Osborne, S., Rickard, C., \& Hall, J. (2010). Clinically-indicated replacement versus routine replacement of peripheral venous catheters. Cochrane Database of Systematic Reviews, 3, CD007798.

SR-2. Gillies, D., Wallen, M.M., Morrison, A.L., Rankin, K., Nagy, S.A., \& O’Riordan E. (2005). Optimal timing for intravenous administration set replacement. Cochrane Database of Systematic Reviews, 4, CD003588.

SR-3. Flint, A., McIntosh, D., \& Davies, M.W. (2005). Continuous infusion versus intermittent flushing to prevent loss of function of peripheral intravenous catheters used for drug administration in newborn infants. Cochrane Database of Systematic Reviews, 4, CD004593.

SR-4. Idvall, E., \& Gunningberg, L. (2006). Evidence for elective replacement of peripheral intravenous catheter to prevent thrombophlebitis: a systematic review. Journal of Advanced Nursing, 55, 715-722. 


\section{2) Randomized controlled trial}

RCT-5. Small, H., Adams, D., Casey, A.L., Crosby, C.T., Lambert, P.A., \& Elliott, T. (2008). Efficacy of Adding 2\% Chlorhexidine Gluconate to 70\% Isopropyl Alcohol for Skin Disinfection Prior to Peripheral Venous Cannulation. Infection Control Hospital Epidemiology, 29, 963-965.

RCT-6. Webster, J., Clarke, S., Paterson, D. et al. (2008). Routine care of peripheral intravenous catheters versus clinically indicated replacement: randomized controlled trial. $B M J, 337,157-160$.

RCT-7. Rickard, C.M., McCann, D., Munnings, J., \& McGrail, M.R. (2010). Routine resite of peripheral intravenous devices every 3 days did not reduce complications compared with clinically indicated resite: a randomized controlled trial. BMC Medicine, 8, 53.

RCT-8. Fink, R.M., Hjort, E., Wenger, B. et al. (2009). The Impact of Dry Versus Moist Heat on Peripheral IV Catheter Insertion in a Hematology-Oncology outpatient Population. Oncology Nursing Forum, 36, 198-204.

RCT-9. Nishanth, S., Sivaram, G., Kalayarasan, R., Kate, V., \& Ananthakrishnan, N. (2009). Does elective re-siting of intravenous cannula decrease peripheral thrombophlebitis: A randomized controlled study. National medical journal of India, 22, 60-62.

RCT-10. Doniger, S.J., Ishimine, P., Fox, J.C., \& Kanegaye, J.T. (2009). Randomized Controlled Trial of Ultrasound-Guided Peripheral Intravenous Catheter Placement Versus Traditional Techniques in Difficult-Access Pediatric Patients. Pediatric Emergency Care, 25, 154-159.

RCT-11. Tripathi, S., Kaushik, V., \& Singh, V. (2008). Peripheral IVs: Factors Affecting Complications and Patency: A Randomized Controlled Trial. Journal of Infusion Nursing, 31, 182-188.

RCT-12. Webster, J., Lloyd, S., Hopkins, T., Osborne, S., \& Yaxley, M. (2007). Developing a Research base for Intravenous Peripheral cannula re-sites: A randomized controlled trial of hospital in-patients. International Journal of Nursing Studies, 44, 664-671.

RCT-13. Perry, A.M., Caviness, A.C., \& Hsu, D.C. (2011). Efficacy of a Near-Infrared Light Device in Pediatric Intravenous Cannulation: A Randomized Controlled Trial. Pediatric Emergency Care, 27, 5-10.

RCT-14. Robinson, P.A., Carr, S., Pearson, S., \& Frampton, C. (2007). Lidocaine is a better analgesic than either ethyl chloride or nitrous oxide for peripheral intravenous cannulation. Emergency Medicine Australasia, 19, 427-432.

RCT-15. Andrew, M., Barker, D., \& Laing, R. (2002). The use of glyceryl trinitrate ointment with EMLA cream for I.V. cannulation in children undergoing routine surgery. Anaesth Intensive Care, 30, 321-325.

RCT-16. Arendts, G., Stevens, M., \& Fry, M. (2008). Topical anesthesia and intravenous cannulation success in pediatric patients: A Randomized double-blind trial. British Journal of Anesthesia, 100, 521-524.

RCT-17. Barría, R.M., Lorca, P., \& Muñoz, S. (2007). Randomized Controlled Trial of Vascular Access in Newborns in the Neonatal Intensive Care Unit. JOGNN, 36, 450-456.

RCT-18. Van Donk, P., Rickard, C.M., McGrail, M.R., \& Doolan, G. (2009). Routine Replacement versus Clinical Monitoring of Peripheral Intravenous Catheters in a Regional Hospital in the Home Program: A Randomized Controlled Trial. Infection control and hospital epidemiology, 30, 915-917.

RCT-19. Black, K.J., Pusic, M.V., Harmidy, D., \& McGillivray, D. (2005). Pediatric Intravenous Insertion in the Emergency Department. Pediatric Emergency Care, 21, 707-711.

RCT-20. Dalal, S.S., Chawla, D., Singh, J., Agarwal, R.K., Deorari, A.K., \& Paul, V.K. (2009). Limb splinting for intravenous cannula in neonates: A Randomized controlled trial. Arch Dis Child Fetal Neonatal Ed, 94, 394-396.

\section{3) Cohort studies}

CS-21. Singh, R., Bhandary, S., \& Pun, K.D. (2008). Peripheral intravenous catheter related phlebitis and its contributing factors among adult population at KU Teaching Hospital. Kathmandu University Medical Journal, 6, 443-447.

CS-22. Abbas, S.Z., de Vries, T.K., Shaw, S., \& Abbas, S.Q. (2007). Use and complications of peripheral vascular catheters: a prospective study. British Journal of Nursing, 16, 648-652.

CS-23. Cicolini, G., Bonghi, A.P., Di Labio, L., \& Di Mascio, R. (2009). Position of peripheral venous cannula and the incidence of thrombophlebitis: an observational study. Journal of Advanced Nursing, 65, 1268-1273. 
CS-24. Panebianco, N.L., Fredette, J.M., Szyld, D., Sagalyn, E.B., Pines, J.M., \& Dean, A.J. (2009). What You See (Sonographically) Is What You Get: Vein and Patient Characteristics Associated With Successful Ultrasound-guided Peripheral Intravenous Placement in Patients With Difficult Access? Academic Emergency Medicine, 16, 1298-1303.

CS-25. Lee, W.L., Chen, H.L., Tsai, TY. et al. (2009). Risk factors for peripheral intravenous catheter infection in hospitalized patients: A prospective study of 3165 patients. American Journal of Infection Control, 37, 683-686.

CS-26. Uslusoy, E., \& Mete, S. (2008). Predisposing factors to phlebitis in patients with peripheral intravenous catheters: A descriptive study. Journal of the American Academy of Nurse Practitioners, 20, 172-180.

CS-27. Subha, Rao S.D., Joseph, M.P., Lavi, R., \& Macaden, R. (2005). Infections Related to Vascular Catheters in a Pediatric Intensive Care Unit. Indian Pediatrics, 42, 667-672.

CS-28. Nassaji-Zavareh, M., \& Ghorbani, R. (2007). Peripheral intravenous catheter- related phlebitis and related risk factors. Singapore Medicine Journal, 48, 733-736.

CS-29. Zarate, L., Mandleco, B., Wilshaw, R., \& Ravert, P. (2008). Peripheral Intravenous Catheters Started in Prehospital and Emergency Department Settings. Journal of Trauma Nursing, 15, 47-52.

CS-30. Lim, M.R. (2008). Incidence of Phlebitis According to Intravenous Therapy in Inpatients. Msc thesis, Keimyung University, Daegu, Korea.

\section{4) Cross-sectional studies, Case-control studies}

CCS-31. Ozyazicioğlu, N., \& Arikan, D. (2008). The effect of nurse training on the improvement of intravenous applications. Nurse Education Today, 28, 179-185.

CSS-32. Johansson, M.E., Pilhammar, E., Khalaf, A., Willman, A. (2008). Registered Nurses' Adherence to Clinical Guidelines Regarding Peripheral Venous Catheters: A Structured Observational Study. Worldviews on Evidence-Based Nursing, 5, 148-159.

CSS-33. Walker, S.R., Farraj, R., Papavassiliou, V., \& Arvanitis, D. (2006). A Descriptive Survey of the Different Management Practices for Peripheral IV Catheters Among Greek, Jordanian, and Australian Teaching Hospitals. Journal of Infusion Nursing, 29, 101-108.

CSS-34. Jacobson, A.F., \& Winslow, E.H. (2005). Variables influencing intravenous catheter insertion difficulty and failure: An analysis of 339 intravenous catheter insertions. Heart Lung, 34, 345-359.

CSS-35. Kim, H.J. (2006). Factors related to the restart of PIV in Hospitalized Children. Msc thesis, Yonsei University, Seoul, Korea.

CSS-36. Jung, J.H. (2009). A Study of Peripheral Intravenous Cannulation \& Intravenous Injection Pain in Hospitalized Children. Msc thesis, Eulji University, Sungnam, Korea.

CSS-37. Yoon, H.S., Park M.A., Park E.J. et al. (2010). Study on Prolonging Peripheral Intravenous Catheter Indwell Time Based on Phlebitis Rate. Journal of Korean Clinical Nursing Research, 16, 145-153.

CSS-38. Sung, S.H., \& Kim, H.S. (2007). Risk Factors of Intravenous Infiltration in Children. Journal of Korean Clinical Nursing Research, 13, 61-72.

CSS-39. Lee, K.S. (2005). Factors related to the duration of PIV in hospitalized children. Msc thesis, Yonsei University, Seoul, Korea.

\section{5) Economic evaluation study}

EE-40. Maenthaisong, R., Chaiyakunapruk, N., \& Thamlikitkul, V. (2006). Cost-Effectiveness Analysis of Chlorhexidine Gluconate Compared with Povidone-Iodine Solution for Catheter-Site Care in Siriraj Hospital, Thailand. Journal of Medicine Assoc Thai, 89, S94-101.

EE-41. Pershad, J., Steinberg, S.C., \& Waters, T.M. (2008). Cost-effectiveness Analysis of Anesthetic Agents During Peripheral Intravenous Cannulation in the Pediatric Emergency Department. Arch Pediatric Adolescent Medicine, 162, 952-961.

\section{6) Non-analysis studies, Expert's opinion}

42. Aziz, A.M. (2009). Improving peripheral IV cannula care: implementing high-impact interventions. British Journal of Nursing, 18, 1242-1246. 
43. Cheung, E., Baerlocher, M.O., Asch, M., \& Myers, A. (2009). Venous access: a practical review for 2009. Canadian Family Physician, 55, 494-496.

44. Cohen, L.L. (2008). Behavioral Approaches to Anxiety and Pain Management for Pediatric Venous Access. Pediatrics, 122, S134-139.

45. Cook, L.S. (2007). Choosing the right intravenous catheter. Home Healthcare Nurse, 25, 523-531.

46. Dougherty, L. (2008). IV therapy: recognizing the differences between infiltration and extravasation. British Journal of Nursing, 17, 896, 898-901.

47. Eggimann, P. (2007). Prevention of intravascular catheter infection. Current Opinion in Infectious Diseases, $20,360-369$.

48. Gabriel, J. (2008). Infusion therapy part one: minimizing the risks. Nursing Standard, 22, 51-56.

49. Gorski, L.A. (2007). Infusion Nursing Standards of Practice. Journal of Infusion Nursing, 30, 151-152.

50. Gorski, L.A. Part 2-Standard 48: Administration Set Change. Journal of Infusion Nursing 2008; 31: 333-335.

51. Gorski, L.A. (2009). Standard 14: Documentation. Journal of Infusion Nursing, 32, 19-20.

52. Gorski, L.A. (2009).Standard 37: Site selection. Journal of Infusion Nursing, 32, 125-126.

53. Gorski, L.A. (2007).Standard 44: Dressings. Journal of Infusion Nursing, 30, 87-88.

54. Gorski, L.A. (2007). Standard 53: Phlebitis. Journal of Infusion Nursing, 30, 265-266.

55. Gorski, L.A. (2007). Standard 54: Infiltration. Journal of Infusion Nursing, 30, 330-331.

56. Gorski, L.A. (2009). The Peripheral Intravenous Catheter: An Appropriate Yet Often Overlooked Choice for Venous Access. Home Healthcare Nurse, 27, 130-132.

57. Halm, M.A, \& Gleaves M. (2009). Obtaining blood samples from peripheral intravenous catheters: best practice?. American journal of critical care, 18, 474-478.

58. Hamilton, H. (2006). Complications associated with venous access devices: part two. Nursing Standard, 20 , 59-65.

59. Ingram, P., \& Lavery, I. (2005). Peripheral intravenous therapy: key risks and implications for practice. Nursing Standard, 19, 55-64.

60. Kathy, L. (2007). Choosing the right vascular access device. Nursing, 37, 38-41.

61. Maki, D.G. (2008). Improving the safety of peripheral intravenous catheters. BMJ, 337, 122-123.

62. Morris, W., \& Heong, Tay M. (2008). Strategies for preventing peripheral intravenous cannula infection. British Journal of Nursing, 17, S14-21.

63. O'Grady, N.P., Alexander, M., Dellinger, E.P. et al. (2002). Guidelines for the prevention of intravascular catheter-related infections. Centers for Disease Control and Prevention. Mobility and Mortality Weekly Report, 51, RR-10.

64. O'Grady, N.P., Alexander, M., Burns, L.A. et al. (2011). Guidelines for the prevention of intravascular catheter-related infections. American Journal of Infection Control, 39, S1-34.

65. Rauch, D., Dowd, D., Eldridge, D., Mace, S., Schears, G., \& Yen, K. (2009). Peripheral Difficult Venous Access in Children. Clinical Pediatrics, 48, 895-901.

66. Rosenthal, K. (2005). Documenting peripheral I.V. therapy. Nursing, 35, 28.

67. Rosenthal, K. (2006). When your patient develops phlebitis. Nursing, 36, 14.

68. Rosenthal, K. (2007). Reducing the risks of infiltration and extravasation. Nursing, 37, 4-8.

69. Scales, K. (2008). Intravenous therapy: a guide to good practice. British Journal of Nursing, 17, S4-S12.

70. Scales, K. (2005). Vascular access: a guide to peripheral venous cannulation. Nursing Standard, 19, 48-52.

71. Thigpen, J.L. (2007). Peripheral Intravenous Extravasation: Nursing Procedure for Initial Treatment. Neonatal Network, 26, 379-384.

72. Vandijck, D.M., Labeau, SO., Secanell, M., Rello, J., \& Blot, S.I. (2009).The role of nurses working in emergency and critical care environments in the prevention of intravascular catheter-related bloodstream infections. International Emergency Nursing, 17, 60-68. 
73. Webster, J., \& Osborne, S. (2009). Phlebitis rate unacceptable. Singapore Medicine Journal, $50,109$.

74. Zempsky, W.T. (2008). The Management of Peripheral Venous Access Pain in Children: Evidence, Impact, and Implementation. Pediatrics, 122, S121-124.

Appendix 4. Recommendations for user before peripheral intravenous catheterization

\begin{tabular}{|c|c|c|c|c|c|}
\hline Recommendations & $\begin{array}{c}\text { Levels of } \\
\text { evidence } \\
\text { (study) }\end{array}$ & $\begin{array}{c}\text { Recomm } \\
\text { endation } \\
\text {-grade }\end{array}$ & $\begin{array}{l}\text { Appropr } \\
\text { iateness }\end{array}$ & $\begin{array}{l}\text { Applica } \\
\text { bility } \\
\mathrm{M}(\mathrm{SD})\end{array}$ & $\begin{array}{l}\text { Effecti } \\
\text { veness }\end{array}$ \\
\hline \multicolumn{6}{|l|}{ 1. Evaluate the demographic characteristics of a child. } \\
\hline $\begin{array}{l}\text { 1-1. The period of peripheral intravenous catheterization is } \\
\text { shorter as the age of a child decreases. }\end{array}$ & $\begin{array}{l}1+(1) \\
2+(2)\end{array}$ & B & $\begin{array}{c}0.64 \\
(0.26)\end{array}$ & $\begin{array}{c}0.61 \\
(0.24)\end{array}$ & $\begin{array}{c}0.61 \\
(0.21)\end{array}$ \\
\hline 1-2. There is no difference in phlebitis between genders. & $2+(2)$ & $\mathrm{C}$ & $\begin{array}{c}0.81 \\
(0.23)\end{array}$ & $\begin{array}{c}0.84 \\
(0.19)\end{array}$ & $\begin{array}{c}0.80 \\
(0.23)\end{array}$ \\
\hline $\begin{array}{l}\text { 2. Verify the disease information. } \\
\text { 2-1. The diagnosis and expected period of treatment should } \\
\text { be verified. }\end{array}$ & $3(2)$ & $\mathrm{D}$ & $\begin{array}{c}0.79 \\
(0.13)\end{array}$ & $\begin{array}{c}0.73 \\
(0.21)\end{array}$ & $\begin{array}{c}0.74 \\
(0.20)\end{array}$ \\
\hline $\begin{array}{l}\text { 2-2. The clinician's previous catheterization experience } \\
\text { should be assessed. In a case where its placement is } \\
\text { difficult, an expert should be chosen to select a method } \\
\text { that is suitable for a child. } \\
\text { Recommendation details }\end{array}$ & $3(2)$ & $\mathrm{D}$ & $\begin{array}{c}0.79 \\
(0.15)\end{array}$ & $\begin{array}{c}0.79 \\
(0.17)\end{array}$ & $\begin{array}{l}0.79 \\
(0.18)\end{array}$ \\
\hline $\begin{array}{l}\text { - Have you had an intravenous injection in the past? } \\
\text { - If so, what difficulties did you have when having the } \\
\text { intravenous injection? } \\
\text { - How many times did the nurse attempt the injection? } \\
\text { - Where did you have the injection? } \\
\text { - Did you have to be re-injected due to a problem } \\
\text { occurring after the injection? }\end{array}$ & & & $\begin{array}{c}0.79 \\
(0.11)\end{array}$ & $\begin{array}{c}0.80 \\
(0.12)\end{array}$ & $\begin{array}{c}0.79 \\
(0.11)\end{array}$ \\
\hline 2-3. Identify risk factors that exist in children. & $3(1)$ & $\mathrm{D}$ & $\begin{array}{c}0.92 \\
(0.07)\end{array}$ & $\begin{array}{c}0.90 \\
(0.10)\end{array}$ & $\begin{array}{c}0.92 \\
(0.07)\end{array}$ \\
\hline $\begin{array}{l}\text { Recommendation details } \\
\text { - Close data collection regarding the child and his/her } \\
\text { physical examination should be performed in order to } \\
\text { prevent complications, i.e. anaphylactic shock, allergy. } \\
\text { (Such as the condition of a vein, chronic disease, } \\
\text { obesity, several attempts at intravenous injection, } \\
\text { decline decrease of blood circulation, availability of } \\
\text { communication regarding self-expression, and the } \\
\text { patient's medication history). } \\
\text { 3. Explain to the child and the caregivers who } \\
\text { participate in the course of intravenous therapy how to } \\
\text { take precautions. }\end{array}$ & & & $\begin{array}{c}0.86 \\
(0.13)\end{array}$ & $\begin{array}{c}0.83 \\
(0.20)\end{array}$ & $\begin{array}{c}0.85 \\
(0.16)\end{array}$ \\
\hline $\begin{array}{l}\text { 3-1. For children younger than three years, it is effective to } \\
\text { explain the course of intravenous therapy by using a real } \\
\text { model as an example as they are unable to understand an } \\
\text { example if an explanation is made through a dummy or } \\
\text { other representative object. The explanation should be } \\
\text { provided in simple and clear words. }\end{array}$ & $3(1)$ & $\mathrm{D}$ & $\begin{array}{c}0.79 \\
(0.18)\end{array}$ & $\begin{array}{c}0.69 \\
(0.27)\end{array}$ & $\begin{array}{c}0.80 \\
(0.19)\end{array}$ \\
\hline
\end{tabular}




\begin{tabular}{|c|c|c|c|c|c|}
\hline Recommendations & $\begin{array}{l}\text { Levels of } \\
\text { evidence } \\
\text { (study) }\end{array}$ & $\begin{array}{l}\text { Recomm } \\
\text { endation } \\
\text {-grade }\end{array}$ & $\begin{array}{l}\text { Appropr } \\
\text { iateness }\end{array}$ & $\begin{array}{l}\text { Applica } \\
\text { bility } \\
\mathrm{M}(\mathrm{SD})\end{array}$ & $\begin{array}{l}\text { Effecti } \\
\text { veness }\end{array}$ \\
\hline $\begin{array}{l}\text { Recommendation details } \\
\text { - Photos or illustration can help the subject remember } \\
\text { the contents of the information provided. } \\
\text { - It is possible to effectively prepare them by allowing } \\
\text { them to observe the catheterization of other children. } \\
\text { - In the case of a child between three and seven years of } \\
\text { age, the preparatory course which is organized } \\
\text { according to stories read by their parents is effective. } \\
\text { For children older than seven years of age, it is more } \\
\text { effective to help them prepare by providing general } \\
\text { information. However, it can be more effective to } \\
\text { provide the least amount of information in case a } \\
\text { patient receives repeated intravenous injections. In } \\
\text { children between six and } 11 \text { years of age, an emotional } \\
\text { explanation should be avoided and the detailed } \\
\text { procedure should be explained, e.g. the arm will be } \\
\text { sterilized; it will be cold.. The course and sensations } \\
\text { should be explained in a stable tone of voice according } \\
\text { to the order of the procedure. }\end{array}$ & & & $\begin{array}{c}0.80 \\
(0.16)\end{array}$ & $\begin{array}{c}0.68 \\
(0.29)\end{array}$ & $\begin{array}{c}0.80 \\
(0.18)\end{array}$ \\
\hline $\begin{array}{l}\text { 3-2. The child's information, such as character and } \\
\text { behavior, is collected from their caregivers while clinicians } \\
\text { provide ways to help the caregivers. }\end{array}$ & $3(2)$ & $\mathrm{D}$ & $\begin{array}{c}0.85 \\
(0.12)\end{array}$ & $\begin{array}{c}0.79 \\
(0.14)\end{array}$ & $\begin{array}{c}0.85 \\
(0.11)\end{array}$ \\
\hline $\begin{array}{l}\text { Recommendation details } \\
\text { - In cases of expected difficulty regarding the } \\
\text { intravenous injection, communication with the child, } \\
\text { the nurses, and doctors is required. Only by } \\
\text { understanding the purpose of the intravenous injection } \\
\text { can the overall course be supported. }\end{array}$ & & & $\begin{array}{c}0.91 \\
(0.09)\end{array}$ & $\begin{array}{c}0.82 \\
(0.20)\end{array}$ & $\begin{array}{c}0.88 \\
(0.11)\end{array}$ \\
\hline $\begin{array}{l}\text { 4. Check the application period of the peripheral } \\
\text { intravenous injection therapy in order to reduce } \\
\text { repeated venipuncture. } \\
\text { 4-1. When peripheral intravenous injection therapy is } \\
\text { needed for more than six days, professional experts should } \\
\text { be educated and secured to apply the peripherally inserted } \\
\text { central catheter (PICC) or midline catheter. }\end{array}$ & $\begin{array}{c}1+(1) \\
3(1)\end{array}$ & B & $\begin{array}{c}0.66 \\
(0.30)\end{array}$ & $\begin{array}{c}0.49 \\
(0.27)\end{array}$ & $\begin{array}{c}0.66 \\
(0.30)\end{array}$ \\
\hline $\begin{array}{l}\text { 5. Use the equipment or tools to evaluate the area of } \\
\text { catheter placement. } \\
\text { 5-1. The hydrothermal therapy performed around the area } \\
\text { of the peripheral intravenous injection helps the area } \\
\text { selection for catheter placement by inducing } \\
\text { vasodilatation. }\end{array}$ & $\begin{array}{c}1+(1) \\
3(1)\end{array}$ & B & $\begin{array}{c}0.77 \\
(0.14)\end{array}$ & $\begin{array}{c}0.76 \\
(0.16)\end{array}$ & $\begin{array}{c}0.79 \\
(0.14)\end{array}$ \\
\hline
\end{tabular}


Appendix 5. Recommendations during peripheral intravenous catheterization

\begin{tabular}{|c|c|c|c|c|c|}
\hline Recommendations & $\begin{array}{c}\text { Levels of } \\
\text { evidence } \\
\text { (study) }\end{array}$ & $\begin{array}{c}\text { Recom } \\
\text { mendat } \\
\text { ion } \\
\text {-grade }\end{array}$ & $\begin{array}{l}\text { Appr } \\
\text { opriat } \\
\text { eness }\end{array}$ & $\begin{array}{l}\text { Applica } \\
\text { bility } \\
\mathrm{M}(\mathrm{SD})\end{array}$ & $\begin{array}{l}\text { Effecti } \\
\text { veness }\end{array}$ \\
\hline $\begin{array}{l}\text { 1. Aim to reduce anxiety among children and to } \\
\text { promote their adaptation during their peripheral } \\
\text { intravenous therapy. } \\
\text { 1-1. Although the presence of caregivers is not always } \\
\text { helpful, family-oriented care has positive effects. } \\
\text { Considering such facts, the presence of caregivers can } \\
\text { help child to remain comfortable during the course of } \\
\text { catheterization. }\end{array}$ & $3(1)$ & $\mathrm{D}$ & $\begin{array}{c}0.72 \\
(0.18)\end{array}$ & $\begin{array}{c}0.74 \\
(0.23)\end{array}$ & $\begin{array}{c}0.65 \\
(0.21)\end{array}$ \\
\hline $\begin{array}{l}\text { 2. Search for the most effective management method } \\
\text { of inserting a peripheral intravenous catheter. }\end{array}$ & & & & & \\
\hline $\begin{array}{l}\text { 2-1. The peripheral intravenous injection team composed } \\
\text { of professional medical experts helps to reduce the } \\
\text { occurrence of potential complications and costs by } \\
\text { preventing the formation of catheter-related infection and } \\
\text { decreasing the risk of infection. } \\
\text { 3. Select the catheter considering the catheter gauge. }\end{array}$ & $\begin{array}{c}1+(2) \\
2++(4) \\
4(1)\end{array}$ & A & $\begin{array}{c}0.86 \\
(0.19)\end{array}$ & $\begin{array}{c}0.77 \\
(0.28)\end{array}$ & $\begin{array}{c}0.86 \\
(0.19)\end{array}$ \\
\hline $\begin{array}{l}\text { 3-1. A catheter with the smallest gauge that allows } \\
\text { appropriate treatment should be selected. }\end{array}$ & $\begin{array}{c}2++(1) \\
2+(1) \\
3(8)\end{array}$ & $\mathrm{C}$ & $\begin{array}{c}0.87 \\
(0.15)\end{array}$ & $\begin{array}{c}0.85 \\
(0.15)\end{array}$ & $\begin{array}{c}.87 \\
(0.15)\end{array}$ \\
\hline $\begin{array}{l}\underline{\text { Recommendation details }} \\
-\quad \text { A small gauge catheter helps to prevent damage in } \\
\text { the intravascular membrane while encouraging blood }\end{array}$ & & & $\begin{array}{c}0.89 \\
(0.10)\end{array}$ & $\begin{array}{c}0.87 \\
(0.10)\end{array}$ & $\begin{array}{c}0.88 \\
(0.11)\end{array}$ \\
\hline
\end{tabular}

flow through the catheter. If the flow of blood is decreased due to an oversized catheter, residual medicine can remain and can cause delayed contact of the catheter to the wall of a blood vessel. Eventually, it causes chemical phlebitis.

- A small-gauge catheter is sufficient to supply the solution. For example, a catheter with 22 gauges can supply $2.5 \mathrm{~L}$ of solution per hour. Thus, there is no difficulty with $3 \mathrm{~L}$ of hydration per day.

4. Maintain hand hygiene when managing intravenous injection.

4-1. Hand hygiene can be guaranteed by using alcohol gel or anti-bacterial soap.

4-2. Gloves are not essential in order to ensure hand hygiene and when using the 'no-touch' technique (No touch after sterilization). However, it is necessary to wear clean gloves so as to protect the medical service provider if the child has an infectious disease or is there is a wound on the clinician's hand.

4-3. Before and after contacting a child as well as before wearing clean gloves, the correct hand hygiene should be performed.

5. Prepare the skin with disinfectant that is effective for preventing complications and is easy to use.

5-1. 2\% Chlorhexidine (CHG) is more effective than other types of disinfectant; however, $70 \%$ alcohol or iodine can also be used for skin preparation.

\begin{tabular}{ccccc}
$1+(1)$ & $\mathrm{B}$ & 0.96 & 0.96 & 0.95 \\
& & $(0.05)$ & $(0.05)$ & $(0.05)$ \\
& & & & \\
$1+(1)$ & $\mathrm{B}$ & & & \\
$3(2)$ & & 0.82 & 0.55 & 0.78 \\
& & $(0.21)$ & $(0.28)$ & $(0.25)$ \\
$3(2)$ & $\mathrm{D}$ & 0.89 & 0.90 & 0.91 \\
& & $(0.19)$ & $(0.09)$ & $(0.09)$ \\
& & & & \\
& & 0.80 & 0.68 & 0.80 \\
$1+(1)$ & $\mathrm{B}$ & $0.16)$ & $(0.29)$ & $(0.18)$ \\
& & $(0.14)$ & $(0.13)$ & $(0.84$ \\
& & & & \\
\hline
\end{tabular}




\begin{tabular}{|c|c|c|c|c|c|}
\hline Recommendations & $\begin{array}{l}\text { Levels of } \\
\text { evidence } \\
\text { (study) }\end{array}$ & $\begin{array}{l}\text { Recom } \\
\text { mendat } \\
\text { ion } \\
\text {-grade }\end{array}$ & $\begin{array}{l}\text { Appr } \\
\text { opriat } \\
\text { eness }\end{array}$ & $\begin{array}{l}\text { Applica } \\
\text { bility } \\
\mathrm{M}(\mathrm{SD})\end{array}$ & $\begin{array}{l}\text { Effecti } \\
\text { veness }\end{array}$ \\
\hline $\begin{array}{l}\text { 5-2. In case of disinfection using iodine, the disinfectant } \\
\text { performance is revealed after the medicine dries. } \\
\text { Therefore, a timer capable of measuring the point in time } \\
\text { that passes two minutes after applying the disinfectant, } \\
\text { after which the catheter should be placed after it is dry. }\end{array}$ & $1+(1)$ & $\mathrm{B}$ & $\begin{array}{c}0.80 \\
(0.29)\end{array}$ & $\begin{array}{c}0.56 \\
(0.29)\end{array}$ & $\begin{array}{c}0.76 \\
(0.27)\end{array}$ \\
\hline $\begin{array}{l}\text { 5-3. A } 70 \% \text { alcohol }+2 \% \text { CHG solution are easy to use } \\
\text { as it dries } 30 \text { seconds after being applied. It is also } \\
\text { effective against coagulase-negative staphylococcus (a } \\
\text { representative catheter-related blood stream bacterial } \\
\text { infection) and Staphylococcus aureus. Thus, it is } \\
\text { recommended to be used for the sterilization of } \\
\text { catheterization. }\end{array}$ & $\begin{array}{c}1+(1) \\
2+(1) \\
3(2)\end{array}$ & B & $\begin{array}{c}0.79 \\
(0.18)\end{array}$ & $\begin{array}{c}0.57 \\
(0.28)\end{array}$ & $\begin{array}{c}0.77 \\
(0.20)\end{array}$ \\
\hline $\begin{array}{l}\text { 5-4. The catheterization area is assumed to be } \\
\text { contaminated if it is touched again with the hands after } \\
\text { sterilization. } \\
\text { 6. Select an area for catheterization that can lower the } \\
\text { possibility of complications and allows easy } \\
\text { maintenance. }\end{array}$ & $\begin{array}{c}1+(2) \\
3(1)\end{array}$ & A & $\begin{array}{c}0.93 \\
(0.11)\end{array}$ & $\begin{array}{c}0.83 \\
(0.25)\end{array}$ & $\begin{array}{c}0.89 \\
(0.22)\end{array}$ \\
\hline $\begin{array}{l}\text { 6-1. The area selected for catheterization should be } \\
\text { discussed with the child and the caregivers. }\end{array}$ & $3(1)$ & $\mathrm{D}$ & $\begin{array}{c}0.85 \\
(0.13)\end{array}$ & $\begin{array}{c}0.75 \\
(0.17)\end{array}$ & $\begin{array}{c}0.80 \\
(0.14)\end{array}$ \\
\hline $\begin{array}{l}\text { 6-2. There is an increased chance of the occurrence of } \\
\text { phlebitis if an intravenous catheter is used in the same } \\
\text { area more than once. }\end{array}$ & $\begin{array}{c}2+(1) \\
3(2)\end{array}$ & $\mathrm{C}$ & $\begin{array}{c}0.79 \\
(0.19)\end{array}$ & $\begin{array}{c}0.77 \\
(0.20)\end{array}$ & $\begin{array}{c}0.80 \\
(0.17)\end{array}$ \\
\hline $\begin{array}{l}\text { 6-3. When selecting an area for catheterization, it should } \\
\text { start from the distal area of the upper-limb while } \\
\text { selecting the area by moving to the proximal area rather } \\
\text { than the area of the previous catheterization, in cases of } \\
\text { re- catheterization. If the area is further distal than that of } \\
\text { the previous catheterization, medicine may leak into the } \\
\text { area where the previous catheter was removed. }\end{array}$ & $3(3)$ & $\mathrm{D}$ & $\begin{array}{c}0.82 \\
(0.16)\end{array}$ & $\begin{array}{l}0.76 \\
(0.16)\end{array}$ & $\begin{array}{c}0.83 \\
(0.15)\end{array}$ \\
\hline $\begin{array}{l}\text { 6-4. A catheter can be dislocated at the bending areas } \\
\text { even by normal movement and when its maintenance } \\
\text { period is short. }\end{array}$ & $\begin{array}{c}1+(1) \\
2+(1) \\
3(8)\end{array}$ & B & $\begin{array}{c}0.89 \\
(0.12)\end{array}$ & $\begin{array}{c}0.85 \\
(0.16)\end{array}$ & $\begin{array}{c}0.85 \\
(0.16)\end{array}$ \\
\hline 6-5. Anticubital fossa should be avoided. & $\begin{array}{c}2+(1) \\
3(6)\end{array}$ & $\mathrm{C}$ & $\begin{array}{c}0.82 \\
(0.15)\end{array}$ & $\begin{array}{c}0.76 \\
(0.13)\end{array}$ & $\begin{array}{c}0.82 \\
(0.15)\end{array}$ \\
\hline $\begin{array}{l}\text { Recommendation details } \\
\text { - If infiltration occurs in this area, it may not be } \\
\text { detected at an early stage. Once the surrounding } \\
\text { tissue is compressed due to the accumulated solution, } \\
\text { the artery and nerves also become compressed and } \\
\text { may thus cause nerve damage and tissue necrosis. }\end{array}$ & & & $\begin{array}{c}0.86 \\
(0.14)\end{array}$ & $\begin{array}{c}0.81 \\
(0.16)\end{array}$ & $\begin{array}{c}0.85 \\
(0.14)\end{array}$ \\
\hline $\begin{array}{l}\text { 6-6. Thrombophlebitis increases as the insertion site } \\
\text { going up from a hand to an arm. } \\
\text { 6-7. When taking a close look around the venous valve, } \\
\text { there are small eminences. When a catheter is placed in } \\
\text { this area, back flow of blood is invisible and the catheter } \\
\text { may penetrate the blood vessel. Therefore, such an area } \\
\text { should be avoided in order to prevent possible } \\
\text { complications. }\end{array}$ & $\begin{array}{c}2++(1) \\
2+(1) \\
3(1)\end{array}$ & B & $\begin{array}{c}0.70 \\
(0.19) \\
0.82 \\
(0.13)\end{array}$ & $\begin{array}{c}0.67 \\
(0.18) \\
0.71 \\
(0.21)\end{array}$ & $\begin{array}{c}0.69 \\
(0.18) \\
0.78 \\
(0.15)\end{array}$ \\
\hline$\frac{\text { Recommendation details }}{<\text { Physical examination }>}$ & & & $\begin{array}{c}0.90 \\
(0.08) \\
\end{array}$ & $\begin{array}{c}0.89 \\
(0.10) \\
\end{array}$ & $\begin{array}{c}0.90 \\
(0.09) \\
\end{array}$ \\
\hline
\end{tabular}




\begin{tabular}{|c|c|c|c|c|c|}
\hline Recommendations & $\begin{array}{l}\text { Levels of } \\
\text { evidence } \\
\text { (study) }\end{array}$ & $\begin{array}{c}\text { Recom } \\
\text { mendat } \\
\text { ion } \\
\text {-grade }\end{array}$ & $\begin{array}{l}\text { Appr } \\
\text { opriat } \\
\text { eness }\end{array}$ & $\begin{array}{c}\text { Applica } \\
\text { bility } \\
\text { M(SD) }\end{array}$ & $\begin{array}{l}\text { Effecti } \\
\text { veness }\end{array}$ \\
\hline
\end{tabular}

- Any injuries to the hands or arms should be examined, e.g. bruise, wound, scar, fracture, etc.

- Membrane and skin elasticity should be examined.

7. It is possible to consider the maintenance of the intravenous injection on the lower $\operatorname{limb}$ for the children younger than seven years of age.

7-1. For the vein, the front and back of the upper limb, including basilic vein, cephalic vein, and metacarpal vein should first be checked.

7-2. The lower limb of an adult is not recommended for an area of catheterization owing to the potential risk of thrombosis and embolism. However, the head, neck, and lower limb can be included in children.

7-3. As the placement of a catheter into an upper limb suppresses the cluster formation more so than catheter placement in the lower limb, it is effective in order to prevent complications.

7-4. In cases of catheterization of a lower limb in children older than eight years of age, the potential dangers of thrombophlebitis which can be generated by unknown causes such as non-movement, the number of blood coagulation factors, dehydration, and circulation disorder, should be explained. Agreement is required and such agreed intention should be documented.

7-5. There is no significant difference in the period of blood vessel maintenance in the upper and lower body in children.

\section{A catheter shall be firmly fixed for maintenance} after its placement.

8-1. If catheter fixation is well-maintained following the catheterization, dislocation of the catheter can be prevented.

Recommendation details

- A well-fixed catheter and the intravenous injection maintenance device can reduce solution leak up to $57 \%$ and infiltration up to $100 \%$.

8-2. A transparent, aseptic dressing shall be applied for frequent monitoring of the catheterized area.

$3(1)$

D

$0.87 \quad 0.88$

0.90

$(0.12) \quad(0.18)$

$3(2)$

D

$\begin{array}{cc}0.79 & 0.72 \\ (0.22) & (0.24)\end{array}$

0.75

$2+(1)$

C

0.78

0.75

0.76

(0.16)

(0.18)

3(1)

$\begin{array}{cc}\mathrm{D} & 0.58 \\ & (0.25)\end{array}$

0.50

0.59

$(0.25)$

$(0.25)$

$1+(1)$

$2+(1)$

B

0.72

0.73

0.72

$(0.20)$

$(0.21)$

$(0.21)$

8-3. The clean and dry condition of the dressing shall be maintained until the next dressing is placed 72 hours later and a loosened, wet or contaminated dressing should be replaced.

8-4. Splints should be used to limit the excessive movement of the catheterized area and to prevent complications.

$\begin{array}{ccc}0.86 & 0.85 & 0.86 \\ (0.10) & (0.08) & (0.10)\end{array}$


Appendix 6. Recommendations after peripheral intravenous catheter

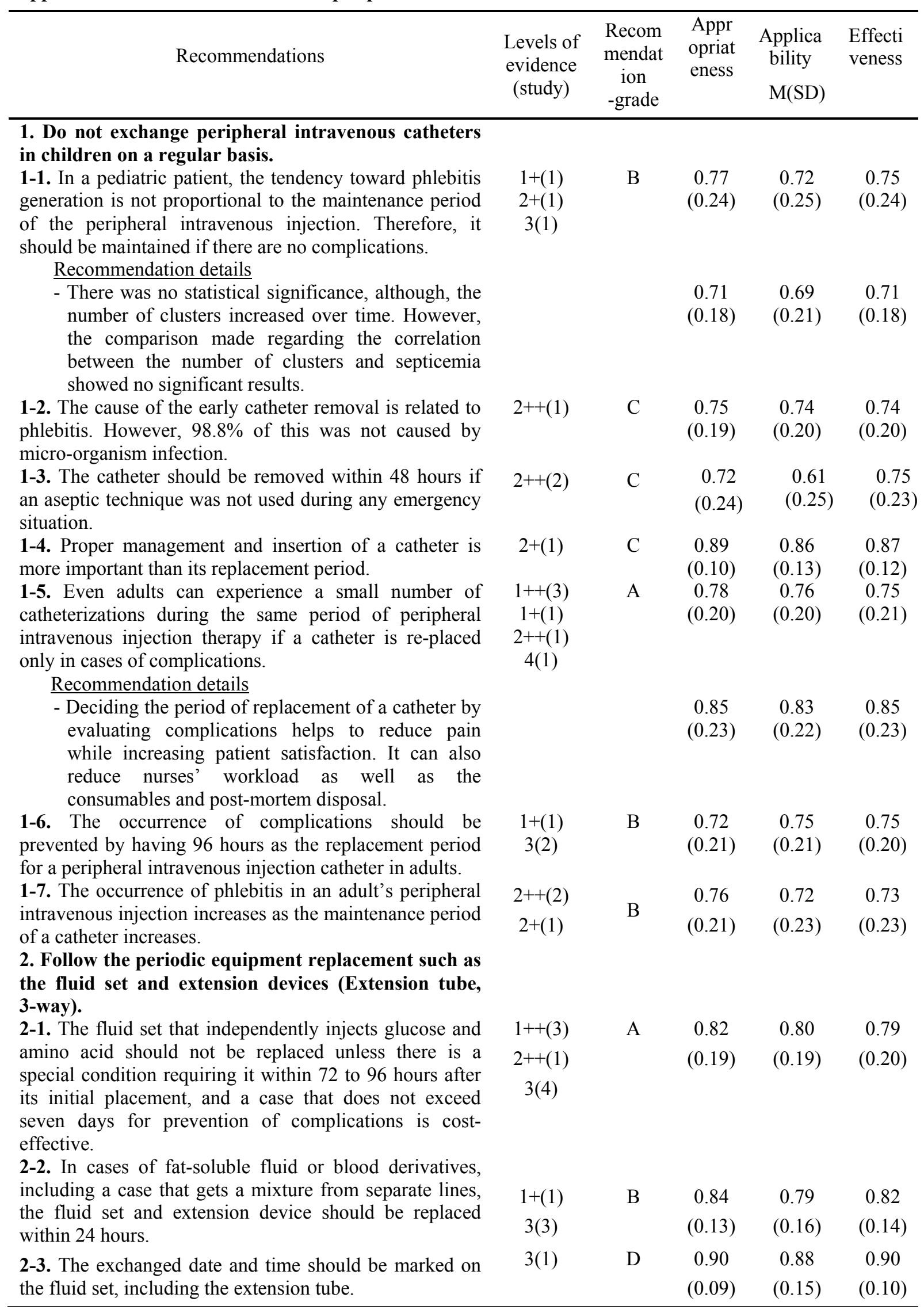




\begin{tabular}{|c|c|c|c|c|c|}
\hline Recommendations & $\begin{array}{l}\text { Levels of } \\
\text { evidence } \\
\text { (study) }\end{array}$ & $\begin{array}{l}\text { Recom } \\
\text { mendat } \\
\text { ion } \\
\text {-grade }\end{array}$ & $\begin{array}{l}\text { Appr } \\
\text { opriat } \\
\text { eness }\end{array}$ & $\begin{array}{l}\text { Applica } \\
\text { bility } \\
\mathrm{M}(\mathrm{SD})\end{array}$ & $\begin{array}{l}\text { Effecti } \\
\text { veness }\end{array}$ \\
\hline $\begin{array}{l}\text { 2-4. As the use of a three-way stop-cock can be a source } \\
\text { of infection, it should be used after sterilization with } 70 \% \\
\text { alcohol or iodine and its cleanness should be maintained } \\
\text { after its use. }\end{array}$ & $1++(1)$ & $\mathrm{B}$ & $\begin{array}{c}0.89 \\
(0.15)\end{array}$ & $\begin{array}{c}0.86 \\
(0.17)\end{array}$ & $\begin{array}{c}0.89 \\
(0.15)\end{array}$ \\
\hline 2-5. The unused three-way stop-cock should be sealed. & $1+(1)$ & B & $\begin{array}{c}0.97 \\
(0.05)\end{array}$ & $\begin{array}{c}0.97 \\
(0.05)\end{array}$ & $\begin{array}{c}0.97 \\
(0.05)\end{array}$ \\
\hline $\begin{array}{l}\text { 2-6. The three-way stop-cock should be replaced every } \\
72 \text { hours. }\end{array}$ & $\begin{array}{c}1++(1) \\
3(2)\end{array}$ & B & $\begin{array}{c}0.68 \\
(0.31)\end{array}$ & $\begin{array}{c}0.66 \\
(0.27)\end{array}$ & $\begin{array}{c}0.64 \\
(0.31)\end{array}$ \\
\hline $\begin{array}{l}\text { 2-7. When the fluid set is replaced according to the } \\
\text { guidelines, the extension device should be replaced as } \\
\text { well. }\end{array}$ & $3(1)$ & $\mathrm{D}$ & $\begin{array}{c}0.93 \\
(0.07)\end{array}$ & $\begin{array}{c}0.91 \\
(0.08)\end{array}$ & $\begin{array}{c}0.93 \\
(0.06)\end{array}$ \\
\hline $\begin{array}{l}\text { 3. Evaluate phlebitis or infiltration objectively. } \\
\text { 3-1. The baseline statement should be established using a } \\
\text { standardized assessment instrument such as the Visual } \\
\text { Infusion Phlebitis (VIP) Score or the INS Standards. }\end{array}$ & $3(3)$ & $\mathrm{D}$ & $\begin{array}{c}0.83 \\
(0.21)\end{array}$ & $\begin{array}{c}0.78 \\
(0.24)\end{array}$ & $\begin{array}{c}0.81 \\
(0.21)\end{array}$ \\
\hline $\begin{array}{l}\text { 3-2. The site where complications occurred, such as } \\
\text { phlebitis, should be evaluated for } 48 \text { hours following the } \\
\text { removal of a catheter. } \\
\text { Recommendation details }\end{array}$ & $3(1)$ & $\mathrm{D}$ & $\begin{array}{c}0.89 \\
(0.12)\end{array}$ & $\begin{array}{c}0.80 \\
(0.22)\end{array}$ & $\begin{array}{c}0.87 \\
(0.13)\end{array}$ \\
\hline $\begin{array}{l}\text { - The risk of having mechanical phlebitis increases } \\
\text { when the maintenance period of a catheter is } \\
\text { extended, a catheter failed to be fixed stably or a }\end{array}$ & & & $\begin{array}{c}0.86 \\
(0.10)\end{array}$ & $\begin{array}{c}0.82 \\
(0.16)\end{array}$ & $\begin{array}{c}0.86 \\
(0.11)\end{array}$ \\
\hline
\end{tabular}

dressing is not replaced.
- As chemical phlebitis is caused by medicine, the speed of the medicine's injection should be reduced and properly diluted medicine should be injected.

- To access edema, the patient's arms should be lifted and if the roundness around the catheter placement area is large and spreads to the sides when lit by a flashlight, it indicates stagnated solution under the skin.

3-3. Even in cases of medication injected using an infusion pump, there should be frequent monitoring.

Recommendation details

- As a certain amount of medicine is introduced through an infusion pump on a regular basis, a medication should be given periodically regardless of internal damage, even in cases of complication generation. As more medicine can be accumulated through the pressure introduced by an infusion pump, thus organ damage can thus be accelerated.

4. Identify the risk characteristics of medications in order to prevent complications.

4-1. As the number of medications is increased in cases of intravenous injection in pediatric patients, the number of days of peripheral intravenous injection maintenance decrease.

4-2. Infection occurs as the interval of injection becomes shorter.

\begin{tabular}{ccccc}
$1+(2)$ & $\mathrm{A}$ & 0.80 & 0.76 & 0.78 \\
$2+(2)$ & & $(0.21)$ & $(0.24)$ & $(0.24)$ \\
$3(1)$ & & & & \\
$1+(1)$ & $\mathrm{B}$ & 0.64 & 0.61 & 0.64 \\
$2+(1)$ & & $(0.25)$ & $(0.22)$ & $(0.24)$ \\
\hline
\end{tabular}




\begin{tabular}{|c|c|c|c|c|c|}
\hline Recommendations & $\begin{array}{l}\text { Levels of } \\
\text { evidence } \\
\text { (study) }\end{array}$ & $\begin{array}{l}\text { Recom } \\
\text { mendat } \\
\text { ion } \\
\text {-grade }\end{array}$ & $\begin{array}{l}\text { Appr } \\
\text { opriat } \\
\text { eness }\end{array}$ & $\begin{array}{l}\text { Applica } \\
\text { bility } \\
\text { M(SD) }\end{array}$ & $\begin{array}{l}\text { Effecti } \\
\text { veness }\end{array}$ \\
\hline $\begin{array}{l}\text { 4-3. There are more cases of phlebitis even using isotonic } \\
\text { solution if irritating medicine, such as KCL, is mixed } \\
\text { with the isotonic solution. }\end{array}$ & $2+(1)$ & $\mathrm{C}$ & $\begin{array}{c}0.86 \\
(0.13)\end{array}$ & $\begin{array}{c}0.86 \\
(0.10)\end{array}$ & $\begin{array}{c}0.86 \\
(0.13)\end{array}$ \\
\hline 4-4. Phlebitis increase when irritating medicine is used. & $\begin{array}{c}1+(2) \\
2+(1) \\
3(2)\end{array}$ & A & $\begin{array}{c}0.87 \\
(0.08)\end{array}$ & $\begin{array}{c}0.88 \\
(0.07)\end{array}$ & $\begin{array}{c}0.88 \\
(0.07)\end{array}$ \\
\hline $\begin{array}{l}\text { Recommendation details } \\
\text { - As the osmotic pressure and } \mathrm{pH} \text { of the highly } \\
\text { concentrated solution (more than } 500 \mathrm{mOsm} / \mathrm{L} \text { of } \\
\text { osmotic pressure) and a solution with a high pH } \\
\text { (more than } \mathrm{pH} 9 \text {, less than 5) cause mechanical and } \\
\text { chemical damage to the intima-media of blood } \\
\text { vessels, the risk of phlebitis increases. }\end{array}$ & & & $\begin{array}{c}0.90 \\
(0.09)\end{array}$ & $\begin{array}{c}0.89 \\
(0.08)\end{array}$ & $\begin{array}{c}0.89 \\
(0.08)\end{array}$ \\
\hline $\begin{array}{l}\text { 4-5. Parenteral nutrition of the particles with high } \\
\text { osmotic pressure cannot be introduced peripherally even } \\
\text { for a short period of time due to the risk of serious } \\
\text { phlebitis and thrombosis. }\end{array}$ & $3(1)$ & $\mathrm{D}$ & $\begin{array}{c}0.75 \\
(0.23)\end{array}$ & $\begin{array}{c}0.68 \\
(0.23)\end{array}$ & $\begin{array}{c}0.75 \\
(0.23)\end{array}$ \\
\hline $\begin{array}{l}\text { 4-6. Bolus injection causes anaphylactic reactions as well } \\
\text { as the risk of speed shock, infiltration, and phlebitis. }\end{array}$ & $3(1)$ & $\mathrm{D}$ & $\begin{array}{c}0.79 \\
(0.19)\end{array}$ & $\begin{array}{c}0.71 \\
(0.17)\end{array}$ & $\begin{array}{c}0.75 \\
(0.16)\end{array}$ \\
\hline $\begin{array}{l}\text { 4-7. Injection should be done with the solution diluted as } \\
\text { much as possible within the limit of drug instructions. }\end{array}$ & $3(2)$ & $\mathrm{D}$ & $\begin{array}{c}0.86 \\
(0.13)\end{array}$ & $\begin{array}{c}0.81 \\
(0.15)\end{array}$ & $\begin{array}{c}0.84 \\
(0.15)\end{array}$ \\
\hline $\begin{array}{l}\text { 4-8. The back flow of blood before injection should be } \\
\text { verified. }\end{array}$ & $3(2)$ & $\mathrm{D}$ & $\begin{array}{c}0.91 \\
(0.09)\end{array}$ & $\begin{array}{l}0.89 \\
(0.14)\end{array}$ & $\begin{array}{c}0.89 \\
(0.13)\end{array}$ \\
\hline $\begin{array}{l}\text { 4-9. When using multi-dose drugs, the vial's cap should } \\
\text { be disinfected with } 70 \% \text { alcohol before use while taking } \\
\text { care not to contaminate it by touching it. }\end{array}$ & $1++(1)$ & B & $\begin{array}{c}0.93 \\
(0.08)\end{array}$ & $\begin{array}{c}0.91 \\
(0.08)\end{array}$ & $\begin{array}{c}0.91 \\
(0.08)\end{array}$ \\
\hline $\begin{array}{l}\text { 4-10. According to the recommendation of the drug } \\
\text { manufacturer, multi-dose drugs should be refrigerated } \\
\text { after being opened. }\end{array}$ & $2++(1)$ & $\mathrm{C}$ & $\begin{array}{c}0.90 \\
(0.13)\end{array}$ & $\begin{array}{c}0.88 \\
(0.13)\end{array}$ & $\begin{array}{c}0.88 \\
(0.13)\end{array}$ \\
\hline $\begin{array}{l}\text { 4-11. With blood products, injection should not exceed } \\
\text { more than four hours and when injecting an independent } \\
\text { or mixed fat-soluble solution, the injection should end } \\
\text { within } 24 \text { hours. } \\
\text { 5. Explain how to monitor complications to the child } \\
\text { or caregivers who maintain the peripheral } \\
\text { intravenous injection. }\end{array}$ & $\begin{array}{c}1+(1) \\
3(3)\end{array}$ & B & $\begin{array}{c}0.90 \\
(0.12)\end{array}$ & $\begin{array}{c}0.88 \\
(0.14)\end{array}$ & $\begin{array}{c}0.90 \\
(0.13)\end{array}$ \\
\hline $\begin{array}{l}\text { 5-1. The information needed to monitor the catheterized } \\
\text { area should be provided to the caregivers and children } \\
\text { who are able to communicate, so that they can } \\
\text { immediately inform the medical experts if there is any } \\
\text { problem related to the peripheral intravenous injection. }\end{array}$ & $3(5)$ & $\mathrm{D}$ & $\begin{array}{c}0.86 \\
(0.10)\end{array}$ & $\begin{array}{c}0.82 \\
(0.08)\end{array}$ & $\begin{array}{c}0.86 \\
(0.10)\end{array}$ \\
\hline
\end{tabular}

